\title{
In-Depth Modernization of HRM in the Public Sector: The Swiss Way
}

\author{
Yves Emery
}

\subsection{INTRODUCTION}

Human resources management (HRM) is undoubtedly the area in the public sector which has evolved the most in the last 25 years, especially in Switzerland. Those in positions of political responsibility in parliaments and executives have realized that a modernization of the public sector cannot be achieved without profoundly reforming HRM statutes and processes; the need was already highlighted quite some time ago (OECD 1997a). Public managers have also often argued that they needed more room for maneuver in managing their staff (Hablützel 2013 ). Even the voting population has supported reforms. In 2000, following a referendum, nearly two-thirds of the voters approved a new status for federal civil servants (now called public employees) by accepting the Swiss Federal Personnel Act (Federal Chancellery 2000). Starting from the simple management of personnel files, HRM in the public sector has become increasingly oriented to strategically managing human

\section{Y. Emery $(\bowtie)$}

IDHEAP, University of Lausanne, Lausanne, Switzerland e-mail: yves.emery@unil.ch

(C) The Author(s) 2019

A. Ladner et al. (eds.), Swiss Public Administration, Governance and Public Management, https://doi.org/10.1007/978-3-319-92381-9_12 
capital (Emery and Chassot 2009). However, this remains a road many public administrations in Switzerland are still traveling; HRM projects continue to converge on this vision.

\subsection{The Progressive Maturation of Human} Resource Management in Swiss Public Administration

The Swiss reforms in human resources are not the result of sudden radical changes. In keeping with Switzerland's tradition of incremental reform (Giauque 2013), they have gradually gathered momentum. A brief look at the genesis of "personnel services" were first created in the 1970s (Germann 1996). Centralized personnel units gave significant impetus to professionalizing HRM in the public sector. In fact, their primary task was to administer personnel statutes by creating regulations and tools - such as grids for classifying jobs and grading systems - which were meant to be applied to all employees. The processes were essentially imposed, meaning mandatory practices were introduced from the top down. The mission was to formulate a set of HRM standards that would establish a basis for treating civil servants equally, to have these standards approved by the political authorities in charge - principally by executives, but on occasion also by parliament in passing statutes governing personnel-and then to implement and control the application of these legal standards.

The idea that human resources are a decisive factor in organizations generally, and in public services in particular, is gradually gaining ground. By the early 1990s, personnel offices began to become interested in the people being managed and not just in their files and data (Emery and Gonin 2009). A parallel can be drawn with changes in operational services to increase their customer-orientation ${ }^{2}$. Specifically, this evolution involves defining and developing the skills, competencies, and behavior of civil servants, in accordance with the expectations of the administration, explicit job specifications, and sometimes competencies frameworks. Personnel recruitment, work evaluations, and training and development are increasingly important, and have benefitted from increased resources. In the

${ }^{1}$ Often called "personnel offices" to highlight the physical space where employees came to discuss their affairs, and at times, to collect their pay.

${ }^{2}$ Or Bürgerorientierung [citizen-oriented] in German; see, for example, Schedler and Proeller (2000). 
wake of such reforms, personnel units are often renamed as human resource departments to highlight their new focus on people rather than just on their files or records.

All such people-centered practices have inevitably led to devolving centralized human resource (HR) services and to move toward a greater decentralization as well as to greater responsibility and accountability by public managers at all levels. Yet the fact that more interest is taken in individuals will not be credible if it is done remotely by human resource specialists who never actually meet with employees themselves. Therefore, a strong emphasis is placed on selecting and training managers in leadership skills and leadership styles, which are designed to develop and motivate public servants. This role of HRM managers, now essential, is illustrated by the orientation taken in publications of the Federal Office of Personnel (2002); they highlight administrative management qualities as a key axis of modernization. This argument is widely found in other European countries as well with welldeveloped training programs for managers (Kuperus and Rode 2008). The creation of "HR respondents" (see below) directly subordinate to operational departments and to those who are meant to work as business partners (Ulrich et al. 2009) contributes to achieving such decentralization.

The final stage of the maturation of Swiss public HRM is, for the most part, yet to come. It is linked to an important vein in the HRM literature which highlights the added value and strategic impact that HRM practices can have on the performance of an organization (Saridakis et al. 2017). This evolution implies the transition from a process orientation to a results orientation, as well as aligning HRM practices with the strategy and objectives pursued by the administration (Barrette 2005). This evolution is doubtless one of the key challenges public sector HRM will face in the next few years, though recent studies tend to highlight more specific challenges, for example, demographic changes or talent management (Giauque et al. 2012a). The fact that there are more and more HR strategies in the administration is an indicator of this evolution to come (see below).

\subsection{Public Sector HRM in Switzerland: The Essential Axes of Modernization}

The metamorphosis in public management resulting from the largescale introduction of New Public Management (NPM) principles has profoundly modified how civil servants do their work (see Chappelet in this volume). At the very least, and for the sake of coherence between 
management systems, HRM should be adapted to meet the new expectations which have arisen from NPM. It calls on training civil servants in new skills and competencies and to rethink the way their performance is evaluated and rewarded. Many analysts even think HRM has been the cornerstone of modernization in many countries (OECD 1997b), as it is an essential lever in bringing about organizational change: it directly affects the profile and behavior of public officials on a daily basis. We think that this has also been true in Switzerland, and so it is worth examining the typical levers for modernizing public HRM in Switzerland.

\subsubsection{Hybrid Public Statutes}

New public sector HRM practices are based on official statutes, often in the form of a law voted on by Parliament; these statutes have evolved considerably. Internationally, public employment conditions have become increasingly aligned with those in the private sector, other than in countries with a long tradition of a career-based system of civil service such as France, Germany, or Austria (Demmke and Moilanen 2010). Most European Union (EU) countries have retained some form of job security for their civil servants, but Switzerland has gone a long way in transforming its statutes, both at federal and cantonal levels, bringing civil service employment conditions closer in line with those found in the private sector (Bellanger and Roy 2013; Wisard 2007). It is also a question of remaining competitive in a labor market where specialized skills and "talents" remain rare. Because of the "open entry" or position-based system of the Swiss civil service, it is crucial that the public employment sector be concerned with how competitive its jobs and compensation packages are.

The deeper evolution of the relevant legal framework illustrates the hybrid nature of what we call the "post-civil service" 3 , since this framework usually provides a public law contract as the legal form of employment (Koller et al. 2011). This was long considered heresy, as it juxtaposed a public law logic (with its basic in legality, equal treatment, proportionality, etc.) with contractual principles. However, it also made it possible for employer and employee together to agree on specific employment arrangements, albeit within the framework of personnel statutes which continues to define the main rights and duties of public employees. It was a very pragmatic Swiss solution, permitting flexibility while maintaining a well-defined legal framework.

\footnotetext{
${ }^{3}$ In line with the post-bureaucratic approach, very popular in the literature.
} 
Moreover, and also a hallmark of Swiss modernization, public employers enjoy considerable autonomy in setting the conditions for their personnel, and as a result, also of their HR processes and tools. Thus, the federal administration, the 26 cantons, and the 2200 -odd municipalities (and in existing public enterprises, where employers have a less formal role), can largely determine their own conditions of employment. This creates a remarkable heterogeneity in what counts as being a "public employee" (Bellanger and Roy 2013; Ladner 2013). It reflects local needs as well as political relations as reflected in the parliaments and at all three governmental levels. In other words, it is a system diametrically opposed to having a unified career civil servant system governed by a single legal framework applying to every public official.

\subsubsection{The Introduction of HR Policies and Strategies}

Legislators increasingly require that civil service statutes include the formulation of an HR policy (Emery and Lambelet-Rossi 2000; Thom and Ritz 2013). It is then up to the government to formulate, and ensure, the implementation of this policy; this complements or completes the juridical-administrative logic of the civil service, giving it a more strategic orientation. Human resource policy can be defined as a strategy for reaching defined goals in the coming years, with the needed actions correspondingly planned ${ }^{4}$. Sometimes, this strategy even forms a part of the master plan of the larger administrative unit, thus creating a link to a more general strategy being pursued. ${ }^{5}$ Thus, the federal administration's new "HR Strategy" for 2016-2019 clearly states that one objective is to be competitive on the labor market: "Thanks to working conditions for personnel which are competitive, the federal government as employer offers interesting and attractive jobs not only for persons of all generations, as well as from the regions and linguistic communities of the country, but also for those who are disabled, and that irrespective of the sex of the persons concerned". ${ }^{6}$

\footnotetext{
${ }^{4}$ See, for example, http://www.pa.zh.ch/internet/finanzdirektion/personalamt/de/ ueber_uns/was_wir_tun/personalmanagement-strategie.html Accessed 14 Sept 2017.

${ }^{5}$ HUG, Strategic axes of the Geneva University Hospitals.

http://www.hug-ge.ch/vision-2020/projets-strategiques

${ }^{6}$ Office fédéral du personnel, Stratégie concernant le personnel 2016-2019 https://www. epa.admin.ch/epa/fr/home/themes/politique-du-personnel/personalstrategie_2016_2019.html Accessed 29 Aug. 2017.
} 
Defining a human resources policy permits the administration to position itself in a clearer, more offensive, and positive way in the labor market. This makes public service employers more attractive in an increasingly competitive market, one in which potential candidates may not necessarily consider working for government as their top priority (Widmer 2010). A study carried out by the author more than 15 years ago indicated that the public administrations of most cantons and larger cities did not have a formalized HR policy (Emery and Lambelet-Rossi 2000). This has changed considerably, though in the absence of empirical data, it is difficult to know precisely how much HR policies in Swiss public administration have developed. Public administrations have become more and more active on their internet sites, as well as in social networks, and take an "employer branding" approach in promoting their distinctive assets, as shown by a recent analysis (Emery and Kouadio 2017). What is evident from this research is that in addition to stressing the legal and material conditions of employment (most notably job security, but including other aspects such as ergonomics), the use of modern HRM practices and leadership, and the many opportunities for personal and professional development, emphasis is given to the value and meaning of the public mission, in conjunction with a so-called public service motivation (Giauque et al. 2012b).

\subsubsection{The Development of a Decentralized Network of $H R$ Professionals}

Although HR services have long handled personnel in a very centralized and even centralizing manner (see above), this situation has changed considerably in the past decade or so. Indeed, so much so that some analysts have begun criticizing what they see as the fragmentation of human resource management in public administration. In doing so, they echo the critique of private enterprises made some 20 years ago, so much had decentralization been pushed there. The rationale in this evolution is linked to a contextualist vision which emphasizes the importance of making decisions at a level "close to the shop floor" so as to better understand the needs, constraints, and challenges of each operational unit concerned (Pichault and Nizet 2013).

In Switzerland, this development has been quite marked. It is not just a matter of a transfer of power between the HR department and the line managers, but also a gradual delegation of competencies between 
parliament and government, which itself delegates certain responsibilities to the public managers as the heads of units. This tendency of having HR decisions being made "closer to the shop floor" is reinforced by the decentralization of HR units as such. To this end, many Swiss administrations have created the role of "HR respondent", a function corresponding to that of a business partner, as the literature puts it (Ulrich 1998). This is a decentralized function, ordinarily dependent on the departmental hierarchy, but-following a functional logicreporting to the centralized HR department. For instance, in the city of Lausanne, HR respondents were established in 2004 in each of the 45 or so administrative services, at an initial ratio of 1 full-time HR respondent for 400 people (Ospel 2011). Such decentralized HR roles are highly developed in the federal administration, most cantonal administrations, and in the larger cities.

\subsubsection{The Professionalization of Recruitment}

A public administration based on merit and professional expertise is one of the defining characteristics of a bureaucratized civil service, according to Max Weber. Yet this does not mean that the skills or competencies required to perform the jobs entrusted to civil servants have been defined and evaluated in a professional manner (Guérard and Pailot 2007). The determination of specific competency profiles, to assess the degree of fit between the position (and its environment) and the person, is a relatively new practice and one that has improved significantly in Swiss public administration. It is the starting point of a professional hiring process which allows one to recruit those with the best skills, for public administration posts that anyone can apply for.

The techniques for evaluating applications which are used in Swiss public administration employ reliable and sophisticated assessment tools which look not only at competencies but also at the professional interests and personality of the candidates (Emery and Gonin 2009). This tendency is attributable to human resource departments which generally have expertise in occupational psychology. Furthermore, these departments are more systematically involved as experts in recruitment processes led by public managers. For a long time, it was entirely up to the political and administrative hierarchy to select personnel, though without always having the necessary expertise. Nowadays, it is not uncommon to have recruitment 
processes, particularly for executive managers, which involve two or three successive interviews along with the involvement of an assessment center, all of which can last more than a day. This does not include soliciting references or conducting other analyses, depending on the post to be occupied; this is especially true for senior management positions.

Finally, public administrations have increasingly resorted to using internal internet portals and both public and private internet job recruitment sites. These promote or accelerate recruitment and help improve the image of the public employer in the labor market-but it is often undertaken without developing a proper marketing strategy (Sivertzen et al. 2013). A presence at recruiting fairs, for example, on university campuses, is now common, though this was not true even 15 years ago.

\subsubsection{Performance Management Is Universalizing}

In line with the NPM's performance orientation, performance management for public employees has been a major topic of modernization in the last 20 years (Gerrish 2016). Numerous analyses have addressed the problem of properly defining the performance of public employees, as well as objectives and criteria for their assessment. The methods implemented in public administrations take into account the specificity of public action and reflect this orientation toward results.

It is the responsibility of line managers at all levels to set goals and assess the performance of their subordinates, while at the same time trying to provide a more participatory, less transactional, and more transformational leadership (van Wart 2013). Performance assessment practices have a long tradition in the private sector, though even there they are not universally accepted (Reyge 2007). In the public sector, these practices are subjected to even greater criticism, even if their introduction is now nearly universal (OECD 2005).

Now widely introduced in Switzerland, the performance management of public employees thus appears as an indispensable practice, one that is basically complementary to mechanisms aiming to introduce performancerelated pay, a theme that is dealt with in the following section. Most current personnel statutes specify that public employees are subject to an annual assessment of their work. And this practice is well accepted, even though it does not always proceed in an optimal fashion, as it is a complex process both from a technical and a human point of view (Vidaillet 2012). 


\subsubsection{Well-Established Performance-Related Pay}

The OECD reported that the 1990s were an era in which, internationally, pay for performance was actively promoted in the public sector (OECD/ PUMA 1997). Such practices were also introduced in Switzerland (Schedler 1993). The experience and the reflection on such practices were very important, not least because it was possible to make needed corrections: the practice of performance-related pay is not self-evident in public organizations (Atkinson et al. 2014).

Today most cantons, as well as the Confederation, have adopted this practice (Bellanger and Roy 2013). An analysis conducted a few years ago by the author in a dozen cantons across Switzerland 7 , however, revealed a country divided between two politico-administrative cultures. Germanspeaking Switzerland is closer to the Anglo-saxon English tradition, which is open to the new principles of public management, while French-speaking Switzerland is closer to the French tradition, corroborating wider findings related to NPM (Giauque and Emery 2008). Apparently, salary increases are near-automatic in French-speaking cantons, though they are subject to budget decisions in parliament, and these may limit or block the increases granted to civil servants. By contrast, the non-payment of the annual salary increase is regarded as a form of sanction for the employee concerned. In German-speaking cantons and in the Confederation, however, pay increases only depend on the performance of the employee, which is evaluated by his or her line manager during the annual evaluation interviews (see above).

The recognition of civil servants through remuneration is a cornerstone of the Swiss modernization of HRM, even when the available budget to do so has not always been up to the expectations of staff members or does not reach the levels theory recommends (Thériault and St-Onge 2006). There are, though, additional forms of financial reward such as bonuses for extraordinary performance, for complex project management, or for suggestions which lead to savings. That is, the available repertoire for this type of reward is often broad, even if its amplitude (meaning the amounts awarded) is limited by internal directives (they rarely exceed $5 \%$ of ordinary pay).

\subsubsection{The Development of Career Paths}

The traditional bureaucratized career system, with its programmed and near-automatic progression up through the ranks, has largely disappeared

${ }^{7}$ Confidential commissioned report. The cantons included Geneva, Vaud, Neuchatel, Fribourg, Bern, Jura, Basel-Stadt, Zurich, Lucerne, and the federal administration. 
in Switzerland, with the exception of a few bodies, such as the police. The current arrangement structures career progression around acquiring new skills and competencies or completing training modules-certification is required in order to assume a higher level of responsibility or to perform more specialized tasks. Such training, or the acquisition of technical, social, and management skills, has been considerably expanded in the last 15 years, making Swiss public administration organizations genuinely qualifying organizations, which further develop the employability of their staff. In most public administrations, training for basic, middle, and senior management is the subject of specific and compulsory seminars, as is true in the federal administration ${ }^{8}$.

In line with international findings (Demmke and Moilanen 2010), civil service careers in Switzerland today are less linear than in the past. That is, they are based less on a kind of automatic and incremental path, independent of the current level of performance, previously largely linked to seniority. They are also less vertical, this classic version of the civil service career having been supplanted by many alternate career paths. In particular, due to internal schemes to increase mobility, the option of moving transversally has been emphasized; it is an effort to decompartmentalize services, offices, and organizational entities more generally. But resistance to this remains significant. The Description des emplois et classification des fonctions (DECFO) project in Vaud's cantonal administration goes in this direction", in a manner similar to the general tools developed in the French interministerial Directorate of Administration and Civil Service (DGAFP 2010).

\subsubsection{The Facilitated Termination of Employment}

In the classic Weberian system, civil servants were sheltered from political pressure through their security of employment and appointment. This special protection has been considerably loosened in Switzerland in recent years, but with respect to employment security, public sector employment remains clearly superior to private sector employment. For this reason, it remains an important (extrinsic) source of motivation for job candidates, and even a competitive advantage, one which can be decisive in a tough labor market.

${ }^{8}$ Office fédéral du personnel, Développement du personnel et des cadres https://www. epa.admin.ch/epa/fr/home/themes/developpement-du-personnel-et-formation/developpement-du-personnel-et-des-cadres.html Accessed 1 Oct 2017.

${ }^{9}$ Canton of Vaud, DECFO-SYSREM http:/ / www.vd.ch/index.php?id=25244 Accessed 2 Oct 2017. 
As for termination, the Swiss tendency has been to facilitate it without prejudice. Therefore, it also lacks the administrative inquiry process (enquête administrative) that was once part of dismissing civil servants from their posts (Emery and Grund 2017). The message is clear, and it concerns as much the legal contract binding civil servant to an employer as the psychological contract involved. Public employment in Switzerland is not guaranteed and an employee can be terminated for economic reasons (e.g., during a restructuring of the administration which results in job cuts), for inadequate performance, or for unacceptable behavior. If a position is eliminated, a comparable position must be offered by the employer in the administration concerned, but should a comparable position not exist, or the employee refuse to take it, then he or she can be dismissed. Similarly, if poor performance or unacceptable behavior is involved, then mandatory objectives are set and evaluated, and a formal warning is sent to the person concerned. If the problem persists, a dismissal can be pronounced.

As far as we are informed, dismissal for unacceptable behavior is relatively rare-contrary to the fears civil service unions expressed when this possibility was introduced. But accurate figures on this are not available and central statistics are lacking, which is, to say the least, surprising.

\subsection{Other Factors Accounting for the Success of THE SWISS HRM MODEL}

The HRM processes mentioned previously are at the heart of the modernization of Swiss public sector HRM. However, other conditions have also favored this modernization:

- The comparatively high level of remuneration paid to Swiss public employees. However, this is not true of senior management positions, where the attractiveness of the private sector is greater, given its freedom to set its own remuneration schemes. ${ }^{10}$ The evidence from the Federal Statistical Office is clear: average salaries in the public sector

\footnotetext{
${ }^{10}$ And that despite the Swiss population approving the "Minder" initiative (named after its initiator) in 2013 which was (https://www.admin.ch/ch/f/pore/vi/vis348t.html Accessed 2 Oct 2017) aimed at limiting the salaries of senior executives in the private sector. According to the latest analyses, it does not seem to have produced the desired effects (http://www. bilan.ch/tag/initiative-minder Accessed 2 Oct 2017).
} 
are higher than in the private sector (Federal Statistical Office 2014). It is not uncommon that, for basic jobs requiring a vocational training qualification (such as the Federal Diploma of Vocational Education and Training) or for jobs requiring a lower level of qualifications, public sector pay is $20 \%$ or $30 \%$ higher than what is offered in the private sector. This salary attractiveness contributes to the evolution of the existing public sector HRM system, in concert with the other fields of modernization noted.

- A fairly pragmatic "social partnership" especially in the Germanspeaking part of Switzerland, where all public management modernization efforts, including those involving HRM, have not led to much political mobilization. This is not the case in French-speaking Switzerland, particularly in Geneva, where reforms to the statutes governing public servants remain the object of strong opposition, particularly from the trade unions. It is exemplified by the Système compétence, rémunération, évaluation (SCORE) project, which tried to reassess remuneration throughout the civil service of the Canton of Geneva. ${ }^{11}$ Launched in 2011, this project is yet to be completed. Still, this example is not representative of the social partnership within the Swiss civil service, where the unions (external to the administration) and the staff committees (internal to the administration) have shown a broad openness to modernization.

- Finally, one should mention the other key players: the political leaders, members of executive bodies, who are open to reforms. Their openness reflects a Swiss culture in which the principles of good organization and generic management (often mistaken for private management) are often welcomed. It should be remembered that many Swiss women and men in politics are career professionals who hold only part-time positions in the various political executives in the country. At the federal level, this particular political career profile of the "militia politician" is changing (Bühlmann et al. 2015). But that many Swiss politicians have experience in the private sector means modernization and innovation in public administration can proceed-even if it is often at an incremental pace (Giauque and Emery 2016).

${ }^{11}$ Canton of Geneva, SCORE, le nouveau système d'évaluation des emplois et des rémunérations http://ge.ch/etat-employeur/service-public/score-nouveau-systeme-devaluation-emplois Accessed 2 Oct 2017. 


\subsection{In Conclusion}

All these public HRM modernization initiatives were made possible in Switzerland by an evolution in the legal framework (statutes)-governing civil servants. They also came about due to a managerialization of public administration, as well as a political context receptive to this type of evolution. It has led to a convergence, in the area of employment, between public and private sectors. It should be remembered, however, that Swiss public sector HRM practices are infinitely more diverse than this brief overview can capture, reflecting the multitude of statutes in force.

\section{REFERENCES}

Atkinson, M. M., Fulton, M., \& Kim, B. (2014). Why do governments use pay for performance? Contrasting theories and interview evidence. Canadian Public Administration, 57(3), 436-458.

Barrette, J. (2005). Architecture de ressources humaines: Perspectives théoriques et pistes de recherche. Relations Industrielles, 60(2), 213-243.

Bellanger, F., \& Roy, C. (2013). Evolution du cadre légal et réglementaire de la fonction publique suisse. In A. Ladner, Y. Emery, J.-L. Chappelet, P. Knoepfel, L. Mader, N. Soguel, \& F. Varone (Eds.), Hanbuch öffentliche Verwaltung (pp. 461-480). Zürich: Neue Zürcher Zeitung libro.

Bühlmann, F., Beetschen, M., David, T., Ginalski, S., \& Mach, A. (2015). Transformation des élites en Suisse. Social Change in Switzerland, 1. Retrieved from http://socialchangeswitzerland.ch

Demmke, C., \& Moilanen, T. (2010). Civil service in the EU of 27: Reform outcomes and the future of the civil service. Berlin: Peter Lang.

DGAFP. (2010). Répertoire interministériel des métiers de l'Etat Politiques d'emploi publiques. Paris: Ministère du Budget, des Comptes publics, de la Fonction publique et de la Réforme de l'État.

Emery, Y., \& Chassot, F. (2009). Evolution de la politique institutionnelle de gestion des ressources humaines: quelles valeurs ajoutées pour la mise en oeuvre des politiques publiques substantielles ? In P. Knoepfel (Ed.), Réforme de politique institutionnelle de gestion des ressources de l'action publique (pp. 137-164). Lausanne: PPUR.

Emery, Y., \& Gonin, F. (2009). Gérer les ressources humaines. Lausanne: PPUR.

Emery, Y., \& Grund, F. (2017). La fonction publique avec ou sans droit disciplinaire. In F. Bellanger \& T. Tanquerel (Eds.), Le droit disciplinaire: instrument nécessaire de l'efficacité administrative ou relique d'une époque répolue? Genève: Schulthess. 
Emery, Y., \& Kouadio, A. B. (2017). Marque employeur et stratégies RH pour les employeurs publics. Le cas du bassin d'emploi Franco-Valdo-Genevois. Management International, 21(2), 47-59.

Emery, Y., \& Lambelet-Rossi, L. (2000). Les politiques du personnel: conception, analyse et recommandations (Vol. 192). Chavannes-près-Renens: IDHEAP.

Federal Chancellery. (2000). Votation no 473, Tableau récapitulatif. https://www. admin.ch/ch/f/pore/va/20001126/det473.html. Accessed 11 Sept 2017.

Federal Statistical Office. (2014). Wage levels - Private and public sectors. https:// www.bfs.admin.ch/bfs/fr/home/statistiques/travail-remuneration/salairesrevenus-cout-travail/niveau-salaires-suisse/secteurs.prive-public.html. Accessed 21 Nov 2017.

Germann, R. E. (1996). Administration publique en Suisse. Berne: Haupt.

Gerrish, E. (2016). The impact of performance management on performance in public organizations: A meta-analysis. Public Administration Review, 76(1), 48-66.

Giauque, D. (2013). L'administration publique fédérale suisse en comparaison internationale: à la recherche d'une tradition administrative. In A. Ladner, J.-L. Chappelet, Y. Emery, P. Knoepfel, L. Mader, N. Soguel, \& F. Varone (Eds.), Manuel d'administration publique suisse (pp. 31-45). Lausanne: PPUR.

Giauque, D., \& Emery, Y. (2008). Repenser la gestion publique. Lausanne: PPUR. Giauque, D., \& Emery, Y. (2016). Les acteurs de l'administration publique au coeur du changement et de l'innovation. In D. Giauque \& Y. Emery (Eds.), L'acteur et la bureaucratie au XXIème siècle (pp. 353-384). Laval/Québec: PUL.

Giauque, D., Anderfuhren-Biget, S., \& Varone, F. (2012a). HRM practices, intrinsic motivators and organizational performance in the public sector. Public Personnel Management, 42(2), 123-150.

Giauque, D., Anderfuhren-Biget, S., \& Varone, F. (2012b). La «guerre des talents» est-elle perdue d'avance? Attirer et fidéliser les salariés par les valeurs du service public. Pyramides. Revue du Centre d'études et de recherches en administration publique, 23, 21-48.

Guérard, S., \& Pailot, P. (2007). Entre concours d'entrée et évaluations des compétences: Recrutement renouvelé des agents publics. In Y. Emery \& D. Giauque (Eds.), Dilemmes de la GRH publique (pp. 109-137). Lausanne: LEP.

Hablützel, P. (2013). Bureaucrates, managers ou concepteurs de systèmes ? L'administration suisse et la direction de l'administration en pleine évolution. In A. Ladner, J.-L. Chappelet, Y. Emery, P. Knoepfel, L. Mader, N. Soguel, \& F. Varone (Eds.), Manuel d'administration publique suisse (pp. 83-97). Lausanne: PPUR.

Koller, C., Heuberger, N., \& Rolland, A.-C. (2011). Monitoring de l'état. Indicateurs pour la mesure comparative des administrations publiques et des 
autorités cantonales. In Working Paper de l'IDHEAP 2 (pp. 1-97). Lausanne: IDHEAP.

Kuperus, H., \& Rode, A. (2008). Hauts fonctionnaires en Europe. Maastricht: EIPA.

Ladner, A. (2013). Etat, système politique et accomplissement de tâches. In A. Ladner, J.-L. Chappelet, Y. Emery, P. Knoepfel, L. Mader, N. Soguel, \& F. Varone (Eds.), Manueld'administration publique suisse (pp. 7-30). Lausanne: PPUR.

OECD (Organisation for Economic Co-operation and Development). (1997a). En quête de résultats. Pratiques de gestion des performances. Paris: PUMA/ OECD.

OECD (Organisation for Economic Co-operation and Development). (1997b). Questions et évolution dans la gestion publique. Paris: PUMA/OECD.

OECD (Organisation for Economic Co-operation and Development). (2005). Performance-related pay for government employees. Paris: OECD.

OECD/PUMA. (1997). La rémunération à la performance pour les cadres de la fonction publique (Vol. 15). Paris: OECD.

Office fédéral du personnel (Ed.). (2002). Führen lehren-Führen lernen (Vol. 15). Berne.

Ospel, L. (2011). Partenaires RH-Perceptions croisées, Ville de Lausanne. (Master Thesis). Geneva: Geneva University.

Pichault, F., \& Nizet, J. (2013). Les pratiques de gestion des ressources humaines: conventions, contextes et jeux d'acteurs. Paris: Points.

Reyge, G. (2007). Evaluation du personnel. Histoire d'une mal-posture. Paris: L'Harmattan.

Saridakis, G., Lai, Y., \& Cooper, C. L. (2017). Exploring the relationship between HRM and firm performance: A meta-analysis of longitudinal studies. Human Resource Management Review, 27(1), 87-96.

Schedler, K. (1993). Anreizsysteme in der öffentlichen Verwaltung. Berne: Haupt.

Schedler, K., \& Proeller, I. (2000). New public management. Berne: Haupt.

Sivertzen, A. M., Nilsen, E. R., \& Olafsen, A. H. (2013). Employer branding: Employer attractiveness and the use of social media. Journal of Product \& Brand Management, 22(7), 473-483.

Thériault, R., \& St-Onge, S. (2006). Gestion de la rémunération: Théorie et pratique. Montreal: Gaëtan Morin.

Thom, N., \& Ritz, A. (2013). Le management public. Concepts innovants dans le secteur public. Lausanne: PPUR.

Ulrich, D. (Ed.). (1998). Delivering results. Boston: Harvard Business Review Book.

Ulrich, D., Allen, N. J., Brockbank, W., Younger, J., \& Nyman, M. (2009). HR transformation. Building HR from the outside in. New York: McGraw Hill. 
van Wart, M. (2013). Lessons from leadership theory and the contemporary challenges of leaders. Public Administration Review, 73(4), 553-565.

Vidaillet, B. (2012). Evaluez-moi! Evaluation au travail: les ressorts d'une fascination. Paris: Seuil.

Widmer, P. (2010). Dans quelle mesure l'administration fédérale est-elle compétitive sur le marché du travail ? Perspective des étudiants et jeunes professionnels du droit. Lausanne: IDHEAP.

Wisard, N. (2007). Le statut de la fonction publique en mutation: contrat de droit public et individualisation des conditions de travail. In Y. Emery \& D. Giauque (Eds.), Dilemmes de la GRH publique. Lausanne: Editions Loisirs et Pédagogie.

Open Access This chapter is licensed under the terms of the Creative Commons Attribution 4.0 International License (http://creativecommons.org/licenses/ by $/ 4.0 /$ ), which permits use, sharing, adaptation, distribution and reproduction in any medium or format, as long as you give appropriate credit to the original author(s) and the source, provide a link to the Creative Commons license and indicate if changes were made.

The images or other third party material in this chapter are included in the chapter's Creative Commons license, unless indicated otherwise in a credit line to the material. If material is not included in the chapter's Creative Commons license and your intended use is not permitted by statutory regulation or exceeds the permitted use, you will need to obtain permission directly from the copyright holder.

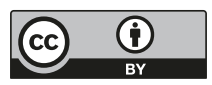

